\section{Olive-mill Waste Compost as a Growth Medium Component for Foliage Potted Plants}

\author{
M. Papafotiou, ${ }^{1}$ G. Kargas, ${ }^{2}$ and I. Lytra ${ }^{3}$ \\ Agricultural University of Athens, Iera Odos 75, 11855 Athens, Greece
}

Additional index words. ornamentals, Codiaeum variegatum, Syngonium podophyllum, Ficus benjamina, growing mix, potting medium, horticultural substrate

\begin{abstract}
Research was carried out to evaluate composted olive-mill waste as a peat substitute in foliage potted plant production. Rooted cuttings of Codiaeum variegatum (L.) A. Juss and Syngonium podophyllum Schott were grown for 5 months and Ficus benjamina L. for 10 months in media containing olive-mill waste compost (OWC), sphagnum peat and perlite in 1:3:4, 1:1:2, and 3:1:4 ratio (by volume), respectively, and their foliage and root growth was determined and compared to a control medium of 1 peat : 1 perlite (by volume). When up to $75 \%$ of peat in the control medium was replaced by OWC, $C$. variegatum foliage and root growth were similar compared with the control, while a $50 \%$ peat replacement gave the best growth. Syngonium podophyllum was more sensitive to peat replacement compared to $C$. variegatum, as only $25 \%$ of peat could be replaced by $\mathrm{OWC}$ without any reduction in foliage growth. The dry weight of the roots was not affected in all media tested. In $F$. benjamina, peat could be replaced up to $75 \%$ without effects on plant height and lateral shoot number, while the length of the laterals was progressively reduced with increasing OWC level. However, only at the highest OWC level ( $75 \%$ peat replacement) the laterals were shorter compared with the control. There was also a progressive reduction of main stem diameter, foliage fresh weight, and root dry weight with increasing OWC level in the medium. Even the lowest OWC level (25\% peat replacement) caused a decrease of foliage and root weight compared with the control, with no effect though on plant visual quality. Even a $25 \%$ peat replacement by OWC caused an increase in bulk density. A considerable decrease of total porosity and readily available water were measured in media where $50 \%$ or $75 \%$ of peat was replaced by OWC. The $\mathrm{pH}$ of the medium with the highest OWC level was high during the first 4 months of culture compared to the other media. The electrical conductivity initially related to $\mathrm{OWC}$ level, but it decreased to values similar to that in the control medium during the first month of culture.
\end{abstract}

Most ornamental pot plants are grown in soilless media, which usually contain peat moss and an inorganic material such as perlite or vermiculite. In recent years, the use of peat as a growth medium component has become an environmental issue, as it is a nonrenewable resource that forms the basis of peat bogs and their specialized ecosystem (Scott and Bragg, 1993), as well as becoming more expensive. Composts from agricultural wastes have the potential to replace a significant proportion of peat in the growth medium of potted ornamental plants (Burger et al., 1997; Papafotiou et al., 2001a, 2001b; Wang and Blessington, 1990).

A parallel environmental issue in the olive oil producing countries of the Mediterranean basin is the treatment and disposal of the olive-mill wastewater, which is the main waste product of olive oil extraction. Biological treatment (Balis et al., 1996; Chatjipavlidis et

Received for publication 10 Feb. 2005. Accepted for publication 25 Mar. 2005.

${ }^{1}$ Assistant professor, Laboratory of Floriculture and Landscape Architecture, Department of Crop Science; e-mailmpapaf@aua.gr.

${ }^{2}$ Lecturer, Laboratory of Agricultural Hydraulics, Department of Land Reclamation and Agricultural Engineering.

${ }^{3}$ Postgraduate student, Laboratory of Floriculture and Landscape Architecture, Department of Crop Science. replace $25 \%$ (by volume) of peat used for the production of poinsettia, however, plant height was reduced.

The object of this study was to investigate the possibility of replacing part of the peat by OWC in the production of foliage pot plants, for which a reduction of plant height is undesirable.

\section{Materials and Methods}

The OWC used was prepared by a method based on that described by Papadimitriou et al. (1997). The composting of olive-mill waste and its chemical characteristics were described by Papafotiou et al. (2004).

Having as a control the medium 1 peat : 1 perlite $(0 \%$ peat replacement by OWC), commonly used as a potting medium for ornamentals, three media with OWC, peat, and perlite were tested. In these media, 25\%, 50\% and $75 \%$ of the peat volume used in the control was replaced by OWC. The media were 1 OWC : 3 peat : 4 perlite $(12.5 \%$ OWC concentration, $25 \%$ peat replacement by OWC), 1 OWC : 1 peat : 2 perlite $(25 \%$ OWC concentration, $50 \%$ peat replacement by OWC) and $3 \mathrm{OWC}: 1$ peat : 4 perlite $(37.5 \%$ OWC concentration, $75 \%$ peat replacement by OWC). A sphagnum peat moss was used with a degree of humification $\mathrm{H}_{3}$ to $\mathrm{H}_{5}$ and a pH of 3.4 to 3.7. The $\mathrm{pH}$ values of the media 1 peat : 1 perlite and 1 OWC : 3 peat: 4 perlite were low and were adjusted to 5.5 and 5.3 , respectively, with limestone. The $\mathrm{pH}$ values of the media 1 OWC : 1 peat : 2 perlite and $3 \mathrm{OWC}: 1$ peat : 4 perlite were 5.8 and 6.3 , respectively. Measurements of the media $\mathrm{pH}$ and electrical conductivity (EC) were made in $1: 2.5$ volume water extracts. Measurements of $\mathrm{pH}$ and $\mathrm{EC}$ after planting were made in three samples from each plant species (samples were randomly chosen each time), and the average values are presented in the result section (see Fig. 3). The physical characteristics of the media were determined in three replicates per medium saturated for $48 \mathrm{~h}$. Samples were prepared by the methods described in FCQAO (1994). EC and $\mathrm{pH}$ were evaluated by the methods of Bower and Wilcox (1965) and Peech (1965), respectively. Bulk density, porosity and water retention were evaluated by the methods of Blake and Hartge (1986), Danielson and Sutherland (1986) and Klute (1986), respectively. Water-retention curves were used to determine the readily available water (RAW), i.e., the quantity of water released when the suction was increased from 10 to $50 \mathrm{~cm}$.

Rooted terminal cuttings of Codiaeum variegatum (L.) A. Juss (croton), Syngonium podophyllum Schott (goose foot plant), and $\mathrm{Fi}$ cus benjamina L. (weeping fig) were obtained from a commercial source and potted in 14-cm (1300-mL) black plastic pots (one plant per pot) in the four growing media on 15 July. From the following week until the end of the experiment, plants were fed weekly with a complete water-soluble fertilizer $20 \mathrm{~N}-11.27 \mathrm{P}-16.6 \mathrm{~K}$ $0.025 \mathrm{Mg}-0.02 \mathrm{~B}-0.05 \mathrm{Cu}-0.10 \mathrm{Fe}-0.05 \mathrm{Mn}-$ $0.001 \mathrm{Mo}-0.05 \mathrm{Zn}\left(2 \mathrm{~g} \cdot \mathrm{L}^{-1}, 400 \mathrm{mg} \cdot \mathrm{L}^{-1} \mathrm{~N}\right)$. The plants were grown in a heated glasshouse and 
were irrigated to ensure adequate leaching from the pot, with frequency depending on green house temperature and solar radiation, plant species and plant age; plants never showed any symptoms of water stress. The experiment with C. variegatum and S. podophyllum was terminated after 5 months of culture (in December), and with $F$. benjamina after 10 months (in May). The length of the main shoot from pot rim to the upper visible node (in all species), as well, as the number and length of lateral shoots developed (in F. benjamina) and the number of leaves (in $C$. variegatum and $S$. podophyllum) were recorded monthly. At the end of the experiment, the fresh weight of the foliage (from plant base) and the dry weight of the roots were measured. Fresh instead of dry weight was regarded as a better indicator for foliage quality. To measure the root dry
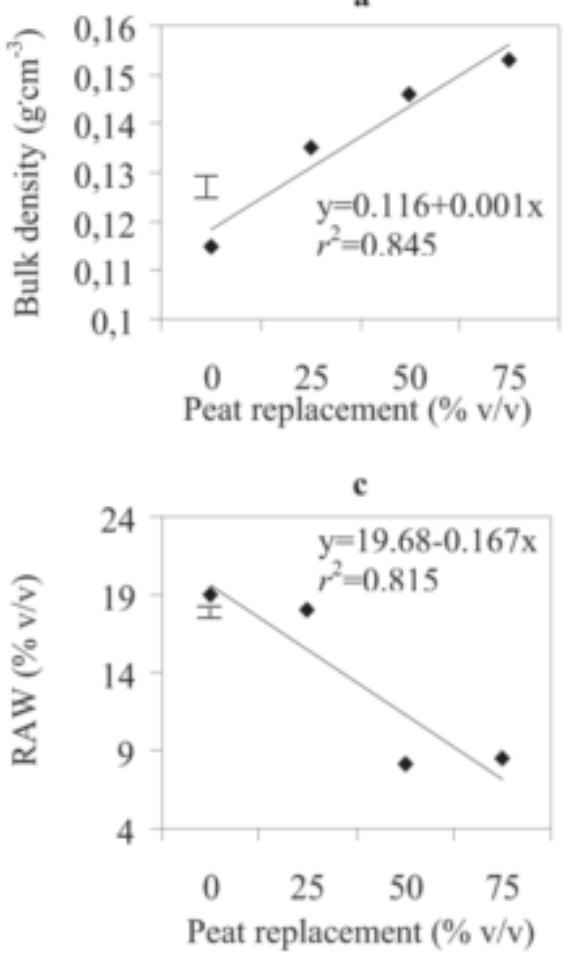

weight, the growth medium was washed off carefully and the roots were oven dried for 72 $\mathrm{h}$ at $75^{\circ} \mathrm{C}$. Additionally, in $\mathrm{F}$. benjamina the main stem diameter at the height of the pot rim was measured. There were 12 plants in each treatment.

Each species was grown separately, with a completely randomized design for treatments within it. The significance of the results was tested by regression analyses and the treatment means were compared by the Tukey-Kramer HSD at $P=0.05$.

\section{Results and Discussion}

Replacement of peat by OWC proportionately increased the bulk density and decreased the total porosity and RAW of the media (Fig. $1 \mathrm{a}-\mathrm{c})$. Media with $50 \%$ and $75 \%$ peat replace-

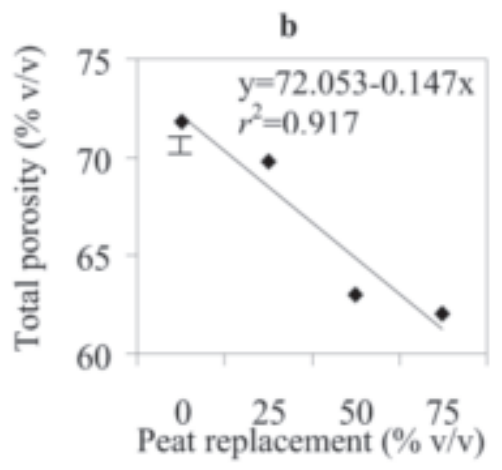

Fig. 1. Values of (a) bulk density, (b) total porosity and (c) readily available water (RAW), of peat-perlite media where peat was partly replaced by olive-mill waste compost(OWC) at the percentages shown. Regression models for $\mathrm{a}, \mathrm{b}$, and $\mathrm{c}$ significant at $P<0.001$. Mean separation by TukeyKramer HSD at $P=0.05$.

Fig. 2. Water content curves of media containing olivemill waste compost (OWC), peat (T) and perlite $(\mathrm{P})$ at the suctions shown. Ratios of media components are by volume. Mean separation in columns by Tukey-Kramer HSD at $P=0.05$.

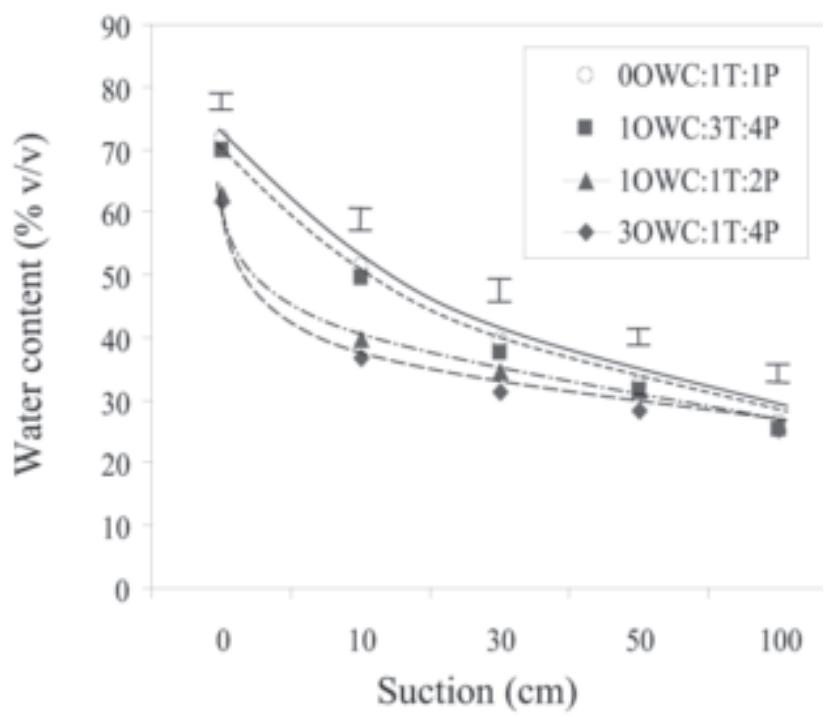

ment had low total porosity and RAW, held less water at saturation and drained faster than the control and the medium with low OWC level, which had similar water content curves (Fig. 2). OWC seemed to have a higher number of small pores than peat, because media with a high OWC level held less water initially than the control, while at $100 \mathrm{~cm}$ suction water retention was similar to the control (Fig. 2). Similar effects on the physical properties of media due to peat replacement by compost have previously been reported (Burger et al., 1997; Papafotiou et al., 2001a, 2001b; Siminis and Manios, 1990).

In S. podophyllum, only $25 \%$ of peat could be replaced by OWC without adversely affecting foliage growth. A higher level of OWC in the medium decreased leaf number and foliage fresh weight, and this was primarily due to earlier senescence of the basal leaves. Plant height was reduced only at the highest OWC level, while root dry weight was not affected (Table 1). In a previous work, S. podophyllum was cultured in a peat-perlite medium, where up to $60 \%$ of peat was replaced by compost from cotton gin trash, with positive effects on foliage and root growth (Papafotiou et al., 2001a). The major difference between media with OWC and media with cotton gin trash compost was their RAW value, as media with $50 \%$ and $60 \%$ peat replacement by cotton gin trash compost had RAW values between that of the peat-perlite control (Papafotiou et al., $2001 \mathrm{~b})$ and the media with $50 \%$ and $75 \%$ peat replacement by OWC (Fig. 1c). So, the low RAW value of media with a high OWC content seem to be the reason for their negative effect on the growth of S. podophyllum. Also, Poole and Conover (1986) have shown that $S$. podophyllum was more sensitive to irrigation than to nutrition and EC.

In $F$. benjamina, plant height and lateral shoot number were not affected even by the highest OWC level, but lateral shoot length was reduced at the highest level and main (woody) stem diameter, foliage fresh weight and root dry weight were reduced even at $25 \%$ peat replacement by OWC (Table 2). In this species, increasing replacement of peat by OWC in the growth medium caused a gradual decrease in lateral shoot length, main stem diameter, foliage fresh weight and root dry weight. The difference in main stem thickness between $F$. benjamina plants grown in the control medium and those in media with OWC was probably the main reason for the reduced foliage weight measured in the OWC media. The characteristic thickening of the main roots of $F$. benjamina was prevented in OWC media. Ficus benjamina was found to grow better in media with a high porosity (Beel, 1988) and is more than likely why, in the present study, it grew more vigorously in the control, as OWC addition decreased the total porosity of the medium(Fig. 1b). Moreover, $F$. benjamina showed a similar response in media where peat was substituted at similar ratios by compost from cotton gin trash (Papafotiou et al., 2001a), which had total porosity values corresponding to media with equivalent OWC concentrations (Fig. 1b). 
In $C$. variegatum, increasing replacement of peat by OWC up to $50 \%$ resulted in a

proportional increase of main stem length, foliage fresh weight and root dry weight, while

Table 1. Foliage and root growth of Syngonium podophyllum after 5 months of culture in peat-perlite media where peat was partly replaced by olive-mill waste compost at the percentages shown.

\begin{tabular}{lcccc}
\hline $\begin{array}{l}\text { Peat } \\
\text { replacement } \\
(\% \mathrm{v} / \mathrm{v})\end{array}$ & $\begin{array}{c}\text { Main stem } \\
\text { length } \\
(\mathrm{cm})\end{array}$ & $\begin{array}{c}\text { Leaf } \\
\text { no. }\end{array}$ & $\begin{array}{c}\text { Foliage } \\
\text { fresh } \mathrm{wt} \\
(\mathrm{g})\end{array}$ & $\begin{array}{c}\text { Root } \\
\text { dry wt } \\
(\mathrm{g})\end{array}$ \\
\hline 0 & $27 \mathrm{a}^{z}$ & $27.7 \mathrm{a}$ & $79.62 \mathrm{a}$ & $7.56 \mathrm{a}$ \\
25 & $28 \mathrm{a}$ & $28.8 \mathrm{a}$ & $77.00 \mathrm{a}$ & $8.09 \mathrm{a}$ \\
50 & $25 \mathrm{ab}$ & $20.1 \mathrm{~b}$ & $59.15 \mathrm{~b}$ & $6.64 \mathrm{a}$ \\
75 & $22 \mathrm{~b}$ & $20.5 \mathrm{~b}$ & $53.03 \mathrm{~b}$ & $6.78 \mathrm{a}$ \\
Significance & $\mathrm{Q}^{*}$ & $\mathrm{Q}^{* *}$ & $\mathrm{~L}^{* * *}$ & $\mathrm{NS}$ \\
\hline
\end{tabular}

${ }^{2}$ Mean separation in columns by Tukey-Kramer HSD at $P=0.05$.

${ }_{\mathrm{NS}, *, *, * * *}^{*}$ Nonsignificant, significant at $P<0.05$ or 0.01 or 0.001 , respectively. $\mathrm{Q}=$ quadratic, $\mathrm{L}=$ linear. Main stem length $\mathrm{y}=26.925+0.054 \mathrm{x}-0.002 \mathrm{x}^{2}, r^{2}=0.289$. Leaf number $\mathrm{y}=28.492-0.047 \mathrm{x}-0.001 \mathrm{x}^{2}$, $r^{2}=0.246$. Foliage fresh wt $\mathrm{y}=84.268-0.431 \mathrm{x}, r^{2}=0.679$.

Table 2. Foliage and root growth of Ficus benjamina after 10 months of culture in peat-perlite media where peat was partly replaced by olive-mill waste compost at the percentages shown.

\begin{tabular}{lcccccc}
\hline $\begin{array}{l}\text { Peat } \\
\text { replacement } \\
(\% \mathrm{v} / \mathrm{v})\end{array}$ & $\begin{array}{c}\text { Main stem } \\
\text { length } \\
(\mathrm{cm})\end{array}$ & $\begin{array}{c}\text { Lateral } \\
\text { shoot } \\
\text { no. }\end{array}$ & $\begin{array}{c}\text { Lateral } \\
\text { shoot } \\
\text { length } \\
(\mathrm{cm})\end{array}$ & $\begin{array}{c}\text { Main } \\
\text { stem } \\
\text { diam } \\
(\mathrm{mm})\end{array}$ & $\begin{array}{c}\text { Foliage } \\
\text { fresh wt } \\
(\mathrm{g})\end{array}$ & $\begin{array}{c}\text { Root } \\
\text { dry wt } \\
(\mathrm{g})\end{array}$ \\
\hline 0 & $74 \mathrm{a}^{2}$ & $18 \mathrm{a}$ & $13 \mathrm{a}$ & $10.7 \mathrm{a}$ & $121.60 \mathrm{a}$ & $12.54 \mathrm{a}$ \\
25 & $80 \mathrm{a}$ & $22 \mathrm{a}$ & $12 \mathrm{ab}$ & $9.6 \mathrm{~b}$ & $93.61 \mathrm{~b}$ & $6.74 \mathrm{~b}$ \\
50 & $78 \mathrm{a}$ & $21 \mathrm{a}$ & $11 \mathrm{ab}$ & $8.7 \mathrm{~b}$ & $85.06 \mathrm{~b}$ & $5.75 \mathrm{~b}$ \\
75 & $74 \mathrm{a}$ & $19 \mathrm{a}$ & $10 \mathrm{~b}$ & $7.6 \mathrm{c}$ & $77.20 \mathrm{~b}$ & $5.44 \mathrm{~b}$ \\
Significance & $\mathrm{NS}$ & $\mathrm{Q}^{*}$ & $\mathrm{~L}^{* * *}$ & $\mathrm{~L}^{* * *}$ & $\mathrm{Q}^{* * * *}$ & $\mathrm{Q}^{* * * *}$ \\
\hline
\end{tabular}

${ }^{2}$ Mean separation in columns by Tukey-Kramer HSD at $P=0.05$.

NS,,$* * *$ Nonsignificant, significant at $P<0.05$ or 0.001 , respectively. $\mathrm{Q}=$ quadratic, $\mathrm{L}=$ linear. Lateral shoot number $\mathrm{y}=19.841+0.106 \mathrm{x}-0.002 \mathrm{x}^{2}, r^{2}=0.180$. Lateral shoot length $\mathrm{y}=13.937-0.042 \mathrm{x}, r^{2}=0.350$. Main stem diameter $\mathrm{y}=10.686-0.041 \mathrm{x}, r^{2}=0.634$. Foliage fresh wt $\mathrm{y}=120-1.158 \mathrm{x}+0.008 \mathrm{x}^{2}, r^{2}=$ 0.820 . Root dry wt $\mathrm{y}=12.220-0.250 \mathrm{x}+0.002 \mathrm{x}^{2}, r^{2}=0.764$.

Table 3. Foliage and root growth of Codiaeum variegatum after 5 months of culture in peat-perlite media where peat was partly replaced by olive-mill waste compost at the percentages shown.

\begin{tabular}{lcccc}
\hline $\begin{array}{l}\text { Peat } \\
\text { replacement } \\
(\% \mathrm{v} / \mathrm{v})\end{array}$ & $\begin{array}{c}\text { Main stem } \\
\text { length } \\
(\mathrm{cm})\end{array}$ & $\begin{array}{c}\text { Leaf } \\
\text { no. }\end{array}$ & $\begin{array}{c}\text { Foliage } \\
\text { fresh wt } \\
(\mathrm{g})\end{array}$ & $\begin{array}{c}\text { Root } \\
\text { dry wt } \\
(\mathrm{g})\end{array}$ \\
\hline 0 & $18 \mathrm{ab}^{z}$ & $24.5 \mathrm{a}$ & $118.37 \mathrm{ab}$ & $4.13 \mathrm{a}$ \\
25 & $20 \mathrm{a}$ & $25.4 \mathrm{a}$ & $122.00 \mathrm{ab}$ & $4.40 \mathrm{a}$ \\
50 & $21 \mathrm{a}$ & $26.6 \mathrm{a}$ & $152.59 \mathrm{a}$ & $5.48 \mathrm{a}$ \\
75 & $16 \mathrm{~b}$ & $25.0 \mathrm{a}$ & $104.27 \mathrm{~b}$ & $3.46 \mathrm{a}$ \\
Significance & $\mathrm{Q}^{*}$ & NS & $\mathrm{Q}^{*}$ & $\mathrm{Q}^{*}$ \\
\hline
\end{tabular}

${ }^{2}$ Mean separation in columns by Tukey-Kramer HSD at $P=0.05$.

${ }^{\text {NS, }}{ }^{*}$ Nonsignificant, significant at $P<0.05$, respectively. $\mathrm{Q}=$ quadratic. Main stem length $\mathrm{y}=17.773+$ $0.162 \mathrm{x}-0.002 \mathrm{x}^{2}, r^{2}=0.153$. Foliage fresh wt $\mathrm{y}=111.023+1.462 \mathrm{x}-0.019 \mathrm{x}^{2}, r^{2}=0.301$. Root dry wt $\mathrm{y}$ $=3.728+0.073 \mathrm{x}-0.001 \mathrm{x}^{2}, r^{2}=0.262$.
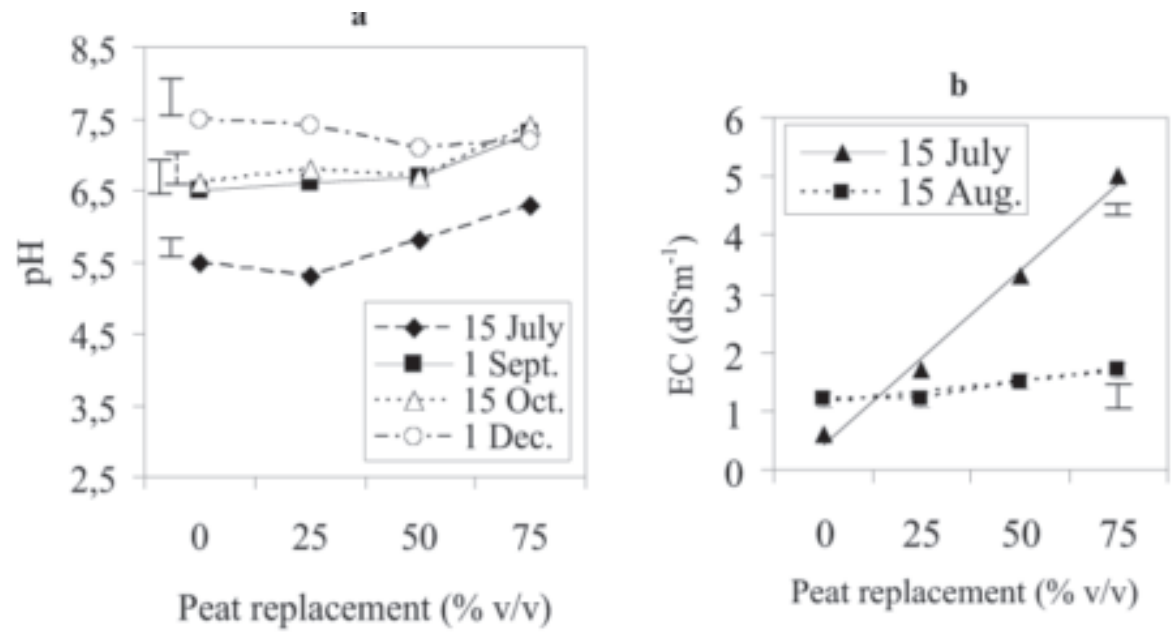

Fig. 3. Values of (a) pH during the first 5 months of the plant culture period and (b) electrical conductance (EC) at the beginning of the plant culture period and 1 month later, of peat-perlite media where peat was partly replaced by olive-mill waste compost (OWC) at the percentages shown. Regression model for EC 15 July $=\mathrm{L}^{* * *}, \mathrm{y}=435.533+60.808 \mathrm{x}, r^{2}=0.988$, regression model for EC 15 Aug. ${ }^{\text {NS }}$ Mean separation on lines by Tukey-Kramer HSD at $P=0.05$. NS, ${ }^{* * * *}$ Nonsignificant, significant at $P<0.001, \mathrm{~L}=$ linear. a further peat replacement up to $75 \%$ caused a decrease of these growth variables. Plants grown in media with $75 \%$ peat replacement by OWC did not differ from the control, but were shorter and had lower foliage fresh weight compared to plants grown in media with $50 \%$ peat replacement (Table 3). So, up to $50 \%$ replacement of peat by OWC was favorable to foliage growth, possibly because of additional nutrition provided by the compost, while after that level inhibition occurred. This inhibition cannot be explained by the physical characteristics of the media, since media with $50 \%$ and $75 \%$ peat replacement had similar physical characteristics (Fig. 1a-c). However, it can be attributed to the increased $\mathrm{pH}$ of the medium with $75 \%$ peat replacement (Fig. 3a), which could have decreased the availability of nutrients, as it has been shown that in a lightweight growing medium, consisted of sphagnum peat, vermiculite, perlite, composted bark and sand, there were sharply decreasing availabilities of a number of nutrients as the pH increased(Peterson, 1981). So, the positive effect on growth by the addition of OWC could not be expressed in this medium. However, the $\mathrm{pH}$ of the medium with the highest OWC level was not that high to affect negatively growth compared to the control. Besides, $C$. variegatum, as well as $S$. podophyllum, was cultured in a peat-perlite medium, where more than half of the peat was replaced by cotton gin trash compost, with positive effects on growth (Papafotiou et al., 2001a), although the pH value of this medium was as high as that of the medium with the highest OWC level.

The increased EC of media with high OWC concentration ( $50 \%$ and $75 \%$ peat replacement) at the beginning of the culture period (Fig. $3 b$ ) did not induce any phytotoxic symptoms on the leaves, possibly because of the low level of $\mathrm{Na}$ ions in the OWC (Papafotiou et al., 2004). After 1 month of culture, all media had similar EC values (Fig. 3b), until the end of the experiment (data not shown). Probably EC did not affect growth of S. podophyllum and $F$. benjamina, since the big reduction of EC in media with $50 \%$ and $75 \%$ peat replacement did not had any positive effect on their growth, expressed as plant height (Figs. 4 and 5). Only $C$. variegatum increased its growth in these media after the first month of culture (Fig. $6)$. Greenhouse temperature had the greatest effect on plant growth, as it prevented shoot elongation when the minimum temperature fell below $17^{\circ} \mathrm{C}$ in October (Figs. 4 to 6).

The decrease of $\mathrm{EC}$ in the media with OWC indicated that the compost had a high level of soluble salts. Similar behavior of EC in potting media with composts has been previously reported (Chong et al., 1991, 1994; Papafotiou et al., 2001a; Siminis and Manios, 1990; Wang and Blessington, 1990). In a parallel experiment, it was found that the EC of the OWC media used in this study fell to the EC level of the control medium, after eleven irrigations with $150 \mathrm{~mL}$ water per experimental pot, every second day, in pots $(14 \mathrm{~cm}$ diameter, $1300 \mathrm{~mL}$ ) without plants and fertilization (data not shown).

A plant for OWC production is already 
working in the western Peloponnese of Greece. Supposing that the total quantities of extracted press cake and olive leaves will be used as starting material, about 200,000 t of OWC could be produced yearly in Greece. This amount is large enough to be considered for use in professional horticulture, provided the amounts of OWC that can be used in the growth media of the various crops has been previously determined. The present study suggests that OWC can replace $25 \%$ of peat in the potting media of S. podophyllum and $75 \%$ of peat in C. variegatum and $F$. benjamina, giving plants of marketable quality. The reduction of stem diameter and lateral shoot length induced by OWC in F. benjamina (Table 2) did not reduce plant marketability. So, OWC can replace a considerable amount of peat in the growth medium of foliage ornamentals, and in this way reduce production cost and contribute to the protection of the environment, as firstly an agricultural waste with toxic effects can be disposed of in an environmental friendly way and secondly the need for peat in floriculture can be reduced, thus preserving peat bog ecosystem.

\section{Literature Cited}

Baddi, G.A., J.A. Alburquerque, J. Gonzalvez, J. Cegarra, and M. Hafidi. 2004. Chemical and spectroscopic analyses of organic matter transformations during composting of olive mill wastes. Intl. Biodeter. Biodegr. 54:39-44.

Baddi, G.A., M. Hafidi, G. Merlina, and J.C. Revel. 2003. Characterization and identification of polyphenols following the treatment of olive mill wastes by composting. Agrochimica 47:161-172.

Balis, C., I. Chatzipavlidis, and F. Flouri. 1996. Olive mill waste as a substrate for nitrogen fixation. Intl. Biodeter. Biodegr. 38:169-178.

Beel, E. 1988. Substrates for greenhouse plants cultivated with several irrigation systems. Acta Hort. 221:315-326.

Blake, G.R. and K.H. Hartge. 1986. Bulk density, p. 363-371. In: A. Klute (ed.). Methods of soil analysis: Part I. Physical and mineralogical methods. 2nd ed. Amer. Soc. Agron.-Soil Sci. Soc. Amer., Madison, Wis.

Bower, C.A. and L.V. Wilcox. 1965. Soluble salts, p. 933-951. In: C.A. Black (ed.). Methods of soil analysis: Part II. Chemical and microbiological properties. Amer. Soc. Agron., Madison, Wis.

Burger, D.W., T.K. Hartz, and G.W. Forister. 1997. Composted green waste as a container medium amendment for the production of ornamental plants. HortScience 32:57-60.

Chatzipavlidis, I., M. Antonakou, D. Demou, F. Flouri, and C. Balis. 1996. Bio-fertilization of olive oil mills liquid wastes. The pilot plant in Messinia, Greece. Intl. Biodeter. Biodegr. 38:183-187.

Chong, C., R.A., Cline, and D.L. Rinker. 1994. Barkand peat-amended spent mushroom compost for containerized culture of shrubs. HortScience 29:781-784.

Chong, C., R.A., Cline, D.L. Rinker, and O.B. Allen. 1991. Growth and mineral nutrient status of containerized woody species in media amended with spent mushroom compost. J.Amer. Soc. Hort. Sci. 116:242-247.

Danielson, R.E. and P.L. Sutherland. 1986. Porosity, p. 443-460. In: A. Klute (ed.). Methods of soil analysis: Part I. Physical and mineralogical methods. 2nd ed. Amer. Soc. Agron.-Soil Sci.

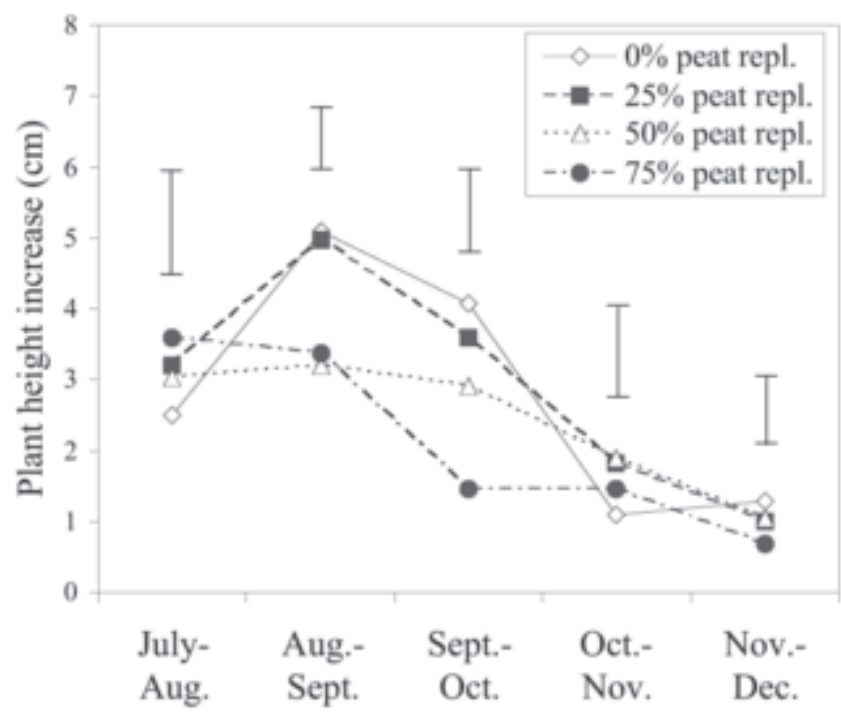

Fig. 4. Effect of peat-perlite media, where peat was partly replaced by olive-mill waste compost (OWC) at the percentages shown, on the monthly height increase of Syngonium podophyllum. Mean separation in columns by TukeyKramer HSD at $P=$ 0.05 .
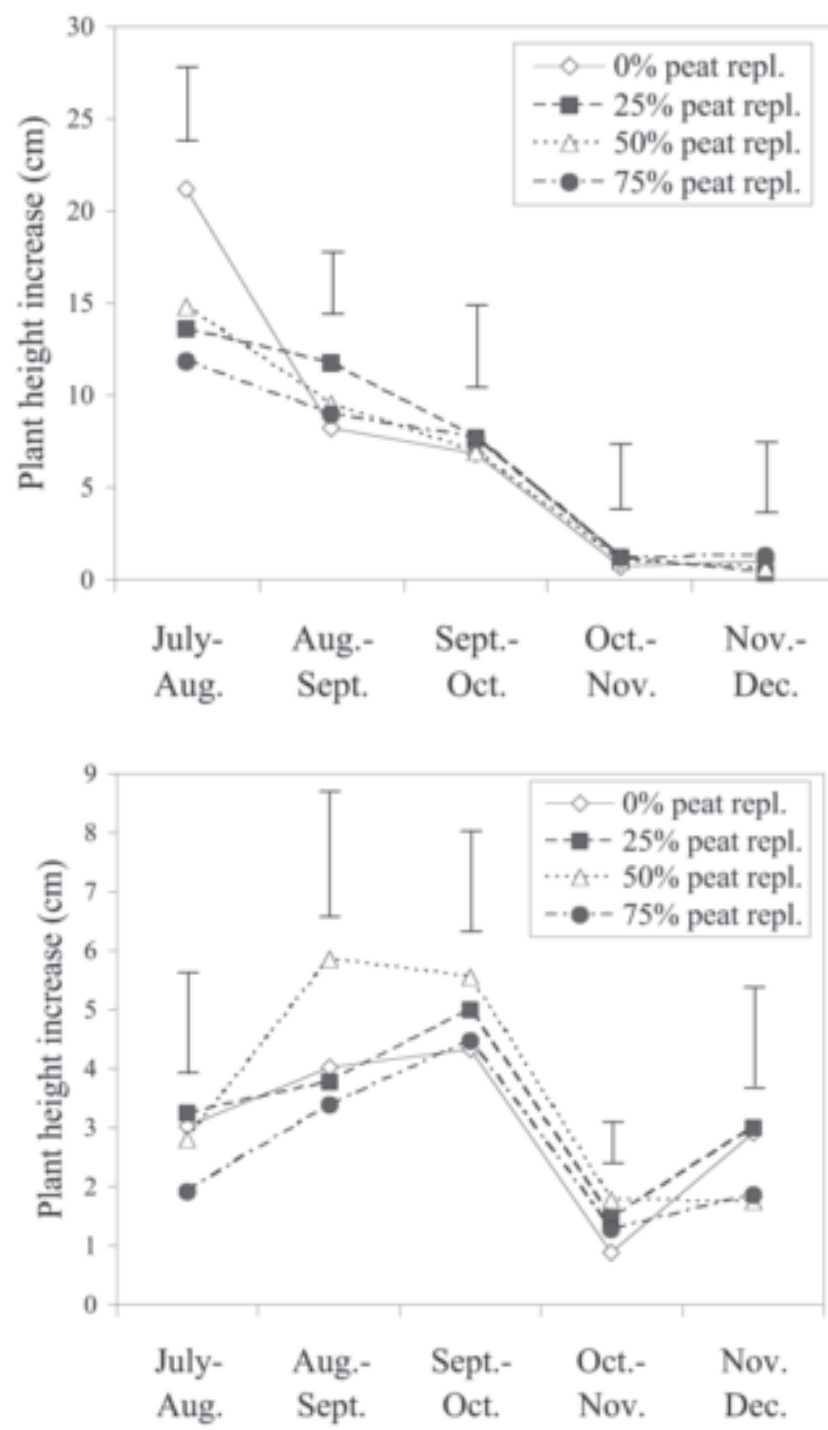

Fig. 6. Effect of peat-perlite media, where peat was partly replaced by olive-mill waste compost (OWC) at the percentages shown, on the monthly height increase of Codiaeum variegatum. Mean separation in columns by TukeyKramer HSD at $P=$ 0.05 . 
Soc. Amer., Madison, Wis.

Federal Compost Quality Assurance Organization. 1994. Methods book for the analysis of compost-in addition with the results of the parallel interlaboratory test 1993, p. 1-8. Fed. Compost Qual. Assurance Org., Stuttgart, Germany.

Klute, A. 1986. Water retention. Laboratory methods, p. 635-53. In: A. Klute (ed.). Methods of soil analysis: Part I. Physical and mineralogical methods. 2nd ed. Amer. Soc. Agron.-Soil Sci. Soc. Amer., Madison, Wis.

Papadimitriou, E.K., I. Chatzipavlidis, and C. Balis. 1997. Application of composting to olive mill wastewater treatment. Environ. Technol. 18:101-107.

Papafotiou, M, V. Asimakopoulou, P. Kouvari, I. Kovaeou, M. Phsyhalou, I. Lytra, and G. Kargas. 2001a. Cotton gin trash compost as growing medium ingredient for the production of pot ornamentals. Gartenbauwissenshaf 66:229-232.

Papafotiou, M, J. Chronopoulos, G. Kargas, M. Voreakou, N. Leodaritis, O. Lagogiani, and S. Gazi. 2001b. Cotton gin trash compost and rice hulls as growing medium components for ornamentals. J. Hort. Sci. Biotechnol 76:431-435.
Papafotiou, M., M. Phsyhalou, G. Kargas, I. Chatzipavlidis, and J. Chronopoulos. 2004. Olive-mill wastes compost as growing medium component for the production of poinsettia. Scientia Hort. 102:167-175.

Paredes, M.J., M. Monteoliva-Sanches, E. Moreno, J. Perez, A. Ramos-Cormenzana, and J. Martinez. 1986. Effect of waste waters from olive oil extraction plants on the bacterial population of soil. Chemosphere 16:1557-1564.

Peech, M. 1965. Hydrogen ion activity, p. 914-926. In: C.A. Black (ed.). Methods of soil analysis: Part II. Chemical and microbiological properties. Amer. Soc. Agron., Madison, Wis.

Perez, J.D., E. Esteban, M. Gomez, and F. GalardoLara. 1986. Effects of wastewater from olive processing on seed germination and early plant growth of different vegetable species. J. Environ. Sci. Heal B 21:349-357.

Peterson, J.C. 1981. Modify your $\mathrm{pH}$ perspective. Florists' Rev. 169(4386):34-35, 92,94.

Poole, R.T. and C.A. Conover. 1986. Growth of cissus, dracaena, and syngonium at different fertilizer, irrigation and soil temperatures. Proc. Fla. State Hort. Soc. 99:268-269.
Sasanelli, N.,P. Greco, T.D'Addabbo, M.I. Coiro, and F. Lamberti. 2003. The use of olive mill wastes for the control of root-knot nematodes. Commun. Agr. Appl. Biol. Sci. 68:135-138.

Sbai, M.L., M. Mebirouk, A. Skalli, Ma Del Carmen Lopez Martinez, and J. Gonzalez. 2000. Phenols biodegradation in olive oil mill wastewater by $A s$ pergillus niger/Phanerochaetae crysosporium, $\mathrm{p}$. 769-775. In: V.A. Tsihrintzis, G.P. Korfiatis, K.L. Katsifarakis, and A.C. Demetracopoulos (eds.). Protection and restoration of the environment (V). vol 2. V. Bouris, Thessaloniki-Kalamaria, Greece.

Scott, M. and N. Bragg. 1993. Digging into composts. Wkshp in combined Proc. Intl. Plant Prop. Soc., 43:150-156.

Siminis, H.I. and V.I. Manios. 1990. Mixing peat with MSW compost. BioCycle 31(Nov):60-61.

Tomati, U., E. Galli, F. Fiorelli, and L. Pasetti. 1996. Fertilizers from composting of olive-mill wastewaters. Intl. Biodeter. Biodegr. 38:155-162.

Wang, Y.T. and T.M. Blessington. 1990. Growth and interior performance of Poinsettia in media containing composted cotton burrs. HortScience 25:407-408. 